[討 論]

\title{
Particular Solution of Cylindrical Shells, Part 1 : An Exact Solution in the Form of Single Seriese」に対する討論
}

（末岡禎佑・川股重也著, 日本建築学会論文報告集・第 263 号, 昭和 53 年 1 月掲載）

$$
\text { 正会員 日 置 興 一 郎 }
$$

貴論に対し私見と質問を述べ，御高見を得たい。

1.1 和文梗概の序にある 風圧仮定に関し「従来行わ れている」とあるのは，本文 (英文) から見れば，「妿つ て行われていた」ではないか。

Timoshenko $0^{1)}$ は文献を示し,Flügge ${ }^{2) 4)} ら^{57}$ は「実際

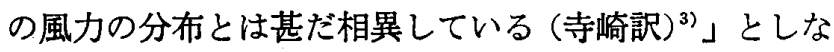
がら $\cos \varphi$ 形の風圧分布を風荷重と呼んでいるのは問題 であるが，日本建築学会関係で筆者の知る範囲でも，古 く 1958.10 に上野がタンクの風圧分布之耐風計算を ${ }^{6}$, 1963 大会 ${ }^{7)}, 1964.7$ 論文集 ${ }^{8}$ には日置らが風圧分布を考 えた円筒款の静力学的応力と固有振動数を論じている。 日置らは既知の二重 Fourier 級数形の厳密解から, 応力 については $n$ 高次まで考えた長い場合に対する雑ではあ るが実用公式まで導いている。これ注学会の鋼製煙突の 規準 ${ }^{10)}$ に採用され出版は 1965.9 で，英国 Ferrybrige の 事故 ${ }^{11}$ が 1965.11.1 に起る以前であった。

1.21968 熊本での事故の報告文献を知りたい。

2. ポテンシャル関数の利用については，筆者らは貴 論の文献 6) に気付かず，媒介関数の名で同次式に対す

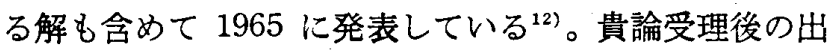
版ではあるが，日置の著書 ${ }^{133}$ にも示され，平板の他円筒 殸の同次解，円筒薄膜理論の一般解が示されている。

2.1 貴論式 (2) では, 微分演算子を含む演算子の割 算の定義はなく，式の演算順序も示されていない。

実質は，割算は $P_{i}$ だけに作用し，それは分母の演算 子を末知数に作用させたものを $P_{i}$ と置いた非同次微分 方程式の特解を求めることを意味し，分子の演算子は後 にその特解に作用させるべきはずであるが如何。式 (5) を式（2）に代入して，式（6）となるためにはこの演算 の約束が必要である。

2.2 荷重をべき級数表示しての一般的な $m$ に対する 特解が可能なのに示されておらず，任意の荷重分布に対 する解となっていないのがおしい。 $\cos n \varphi$ 展開での特解 は, 二重 Fourier 級数, べき級数形の他, 次の表現もあ る。 $x=\xi$ 一定線上の線荷重 $P_{i}(\xi)=1$ に対する特解を $\delta_{i}(x, \xi)$ とすると, 一般的荷重 $P_{i}(x)$ の特解は, $\int P_{i}$
( $\xi) \delta_{i}(x, \xi) d \xi$ の形で求まる。閉円筒では， $X_{0}, X_{1}, Y_{0}$, $Y_{1}+Z_{1}$ 以外の荷重成分に対しては合力が需となるので, 解梳 $\int_{-\infty}^{\infty} P_{i}(\xi) \delta_{i}(x-\xi) d \xi$ の形で示せる。この $\delta_{i}(x, \xi)$ は同次解から定めることができ，筆者が同次解を厳密に 検討した ${ }^{14}$ 理由の一つでもある。

2.3 特解は，方程式を满たすか否かは検討できても 他の特解との定量的比較は共通の境界条件としなければ 難しいのではないか。これは貴論 §3にもふれてある通 りで，表 2 からの結論は慎重を要す。和文梗概で「表 2 から次のことがわかる」とあるのは本文（英文）から見 れば「表 2 では次のことがいえる」ではないのか。

2.4 貴論 p. 52 上 1 行にもあるように，荷重分布が 急変する場合薄膜理論の近似性が落ちるのは, $\varphi$ 方向 $(n$ 大）だけでなく, $x$ 方向 $\left(m\right.$ 大) でもそうで, Flügge ${ }^{5)}$ は精しく論じている。表 2 から ii）の結論は言い切れな い。一方薄膜特解には, 荷重急変でも厳密解である $Y$ 。 項やポアソン比の影響を除けば厳密解となる $X_{0}, X_{1}, Y_{1}$ の項があるから, 荷重分布の急変が常に薄膜特解の近似 度を落とすとも言い切れない。

2.5 ポテンシャル関数は考えている方程式に対応寸 るもので，曲げ理論のそれと，薄膜理論のそれを比較す る意味は何か。共通な量である変位, 面内力について比 較すべきでないか。筆者は同次解に対し長さを $し$ とし変 位について $n^{4}\left(n^{2}-1\right)^{2}(l / a)^{4}(t / a)^{2} / 48 \ll 1$ の精度で, 薄 膜解は綮密解の近似と見なせるとしている ${ }^{14)}$ 。

\section{文献}

1) Timoshenko, Woinowsky-Krieger : Theory of Plates and Shells, McGraw-Hill, 1959

2) Flügge : Statik und Dynamik der Schalen, Springer, 1934

3）寺崎恒正 (訳) : 曲面板の力学, コロナ社, 1954

4) Flügge : Stresses in Shells, Springer, 1962

5) Pflüger : Flementare Schalenstatik, Springer, 1957

6）上野 誠：日本建築学会論文報告集 60, 1958, p. 237

7）日置：日本建築学会論文報告集 89, 1963， p. 231

8）日置・羽原：日本建築学会論文報告集 $100,1964.7$

9) Heki, Habara : Memoirs Fac. Eng. Osaka City Univ. 6, 1964

10）日本建築学会 : 銅製煙突構造計算規準 - 同解説, 1965.9

11) Paduart : Bull. IASS, 36, 1968. 12, pp. 45-50 
12) Heki, Habara : Proc. 15th Jap. Nat. Cong. Appl. Mech. 1965, pp. 1-4, 1966
13）日置 : 構造力学 II，朝倉書店，1977.11

14）日置：日本建築学会論文集 49, 1954.9, pp. 55-61

\section{日置興一郎氏の討論に対する回答}

$\begin{array}{llll}\text { 正会員 末 } & \text { 岡 } & \text { 禎 } & \text { 佑 } \\ \text { 正会員 川 } & \text { 股 } & \text { 重 } & \text { 也 }\end{array}$

1.1 和文梗概の序にある「従来行われている」は，本 文 (英文)にあるように，「かつて行われていた」が正し い。

討論者（日置氏）が挙げておられる文献 6)〜9）のよ 5に，円筒シェルにかかる風圧力の分布を正確な形で応 力解析に反映させるための学問的な努力や実際的な規準 が存在していたにもかかわらず，その成果が薄肉シェル の容器の設計に取入れられていたかどうかは疑問であ る。容器類に対する風圧力の重要さは, 構造体の規模の 报大にともなって，改めて認織しなおす必要がある。

討論者の引用文献 7)，8）沖細長い煙突に対する風圧 力を対象として，既存の二重 Fourier 級数形式の特解を 近似化して，使い易い形の公式を導いたものである。こ れに対して，筆者 (末岡・川股) が本論文で提出したの は，Goldenveizer (1961)，日置（1965）らが用いたのと 同じ荷重ポテンシャル関数 (媒介関数) の手法を使って， 閉じた円筒殼について正確で能率的な曲げ応力の解析を 可能にする単級数形式の特解を悠密な形で求めたもので ある。

1.2 朝日新聞 (夕刊) 昭和 43 年 9 月 25 日, 第 3 版, p. 11 の記事参照。

事故の調查報告書の有無は不明である。

2.1 微分演算子 $D$ を利用した微分方程式の解法にお いて, $1 / f(D)$ 演算 $f(D)$ の逆演算，すなわち $f(D)$ に対応する積分操作を表わすことは常織であると考えら れる（たとえば文献 1， p. 114，pp. 265-266)。 $d y / d x$ を定義なしで用いるのと同じ意味で $1 / f(D)$ を定義なし で用いた。

(2) 式から（6) 式を導くにあたっては, 演算子の関数 $A+k \bar{A}$ を普通の有理式と同様に扱っている（根拠はた とえば文献 1，p.114）。すなわち，(5) 式を（2）式に 代入すると, 分母と分子に同じ $A+k \bar{A}$ が来るから, こ れを約分して (6) 式が得られる。演算の実質的な内容は 討論者が主張されているとおりである。

2.2 特解に種々の形式があり得ることは, 特解の性 格より当然である。本論では，実用上重要な意味をもつ， 母線方向の分布形が低次のべき級数で表わされる荷重に 対する特解を求めることを主目的とした。
なお，御指摘の任意べきに対する特解は，付記のよう な形で求められている。

2.3 厳密な特解之膜理論による特解との定量的な比 較は，表 2 をもとにしては行っていない。討論者が主張 されていると扔りに，\$3において共通の境界条件のも とで比較を行っている。

\section{4 およひ 2.5}

ii）の文章は, 2 種の荷重ポテンシャル関数の形を比較 したのであって, 薄膜理論の近似度については直接言及 していない。i）と ii) で荷重ポテンシャル関数を比較し ているのは, 悠密解においても薄膜解においても, 変位 および応力が荷重ポテンシャル関数から同種の演算によ って導かれる以上, 荷重ポテンシャル関数の形が異れば 変位および応力の形が異って来るからである。なお，特 解の相違がそのまま解全体の相違とならないことは同次 解の存在から当然だとしても, 荷重ポテンシャル関数の 形が異れば解全体が異る可能性があると言える。

特解の精度は，同次解と組合わせた場合を論じないと 意味がないので, 討論者が同次解に関して示しておられ るような, パラメトリックな精度の表示が, 特解に関し て可能であると思われない。

\section{引用 文 献}

1）矢野健太郎，“微分方程式”，第 3 版，掌華房，1958

附 祀 円周方向に Fourier 級数で, 母線方向にべき級数で 表わされる面に垂直な荷重 $z$ に対する荷重ポテンシャル関数 $F_{3}$ $(\xi, \varphi)$

荷重 $\boldsymbol{z}$ が次のように表わされるものとする。

$$
-\frac{a^{2}}{B} z=P_{\mathrm{s}}=P_{m n} \xi^{m} \cos n \varphi
$$

荷重ポテンシャル関数 $F_{3}(\xi, \varphi)$ を次のように仮定する。

$$
F_{8}(\xi, \varphi)=F_{3 n}(\xi) \cos n \varphi
$$

関数 $F_{s n}(\xi)$ は次式より決定される。

$$
\begin{aligned}
& {\left[a_{8} \frac{d^{8}}{d \xi^{8}}+a_{6} \frac{d^{8}}{d \xi^{\mathrm{g}}}+a_{4} \frac{d^{4}}{d \xi^{4}}+a_{2} \frac{d^{2}}{d \xi^{2}}+a_{0}\right] F_{3 n}(\hat{\xi}) \cos n \varphi} \\
& =-\frac{2 P_{m n}}{(1-\nu)} \xi^{m} \cos n \varphi
\end{aligned}
$$

ただし，

$$
\begin{aligned}
& a_{0}=n^{4}\left(n^{2}-1\right)^{2} k \\
& a_{2}=-2 n^{2}\left[2 n^{4}-(4-\nu) n^{2}+(2-\nu)\right] k \\
& a_{4}=\left(1-\nu^{2}\right)+\left[6 n^{2}\left(n^{2}-1\right)+\left(4-3 \nu^{2}\right)\right] k \\
& a_{6}=-2\left(2 n^{2}-\nu\right) k \\
& a_{8}=k
\end{aligned}
$$

(i) $n=0,1$ の場合

（3）式において $a_{0}=0 ， a_{2}=0$ となり積分することによって次 